\title{
The Effects of Rabbit Manure-Derived Biochar on Soil Health and Quality Attributes of Two Mine Tailings
}

\author{
Eliana Cárdenas-Aguiar ${ }^{1,2}$, Ana Méndez ${ }^{2, *} \mathbb{0}$, Jorge Paz-Ferreiro ${ }^{3}\left(\mathbb{D}\right.$ and Gabriel Gascó $^{1}$
}

1 Department of Agricultural Production, Universidad Politécnica de Madrid, Ciudad Universitaria, 28040 Madrid, Spain; eliana.cardenas.aguiar@alumnos.upm.es (E.C.-A.); gabriel.gasco@upm.es (G.G.)

2 Department of Geological and Mining Engineering, Technical University of Madrid, 28040 Madrid, Spain

3 School of Engineering, RMIT University, Melbourne, VIC 3001, Australia; jorge.paz-ferreiro@rmit.edu.au

* Correspondence: anamaria.mendez@upm.es

check for updates

Citation: Cárdenas-Aguiar, E.; Méndez, A.; Paz-Ferreiro, J.; Gascó, G. The Effects of Rabbit Manure-

Derived Biochar on Soil Health and Quality Attributes of Two Mine Tailings. Sustainability 2022, 14, 1866. https://doi.org/10.3390/su14031866

Academic Editor: Salvatore Cataldo

Received: 23 December 2021

Accepted: 2 February 2022

Published: 6 February 2022

Publisher's Note: MDPI stays neutral with regard to jurisdictional claims in published maps and institutional affiliations.

Copyright: () 2022 by the authors Licensee MDPI, Basel, Switzerland. This article is an open access article distributed under the terms and conditions of the Creative Commons Attribution (CC BY) license (https:// creativecommons.org/licenses/by/ $4.0 /)$.

\begin{abstract}
Biochar amendment is becoming a promising technology for mining soil restoration. The addition of biochar can improve soil microbiological parameters related to soil quality, such as enzyme activities. The aim of the present research was to evaluate the effect of rabbit manure (RM) and two rabbit manure biochars prepared at two pyrolysis temperatures $\left(300\right.$ and $\left.600{ }^{\circ} \mathrm{C}\right)$ on the biochemical properties of two mining soils in the Portman area (Spain) in the presence or absence of vegetation. Soils were amended with the RM, the two biochars and a mixture of the rabbit manure and biochars $(50 / 50 w / w)$ at a rate of $10 \%$ in a mesocosms experiment to study the changes in dehydrogenase, phosphomonoesterase, $\beta$-glucosidase activities, geometric mean of enzyme activities (GMea) and soil microbial biomass (SMB). Changes in individual enzyme activities were not always consistent. However, when using the GMea as a measure of soil quality, our results showed an increase in the GMea (217-360 times) after the addition of rabbit manure to mining soils, while this increase was from 81-270 times following the addition of rabbit manure with biochar prepared at $300^{\circ} \mathrm{C}$. Therefore, the use of biochar prepared at low temperatures could be a promising direction for the improvement of soil quality and soil carbon sequestration.
\end{abstract}

Keywords: soil quality; biochar; enzyme activities; rabbit manure; Brassica napus

\section{Introduction}

Soils play an important role in the circular economy as they store mineral materials, while providing renewable and bio-based resources. Soils are crucial in their role in closing the biogeochemical cycles for water, nutrients and carbon. For this reason, soil conservation and the improvement of soil quality is fundamental to secure the future provision of natural resources and services for a growing world population [1]. Soil is a non-renewable resource that must be conserved, particularly peatlands, which are able to sequester $312.1 \mathrm{Gt}$ of carbon dioxide [2]. For example, 100 years are necessary for the formation of $0.8 \mathrm{~cm}$ of peat in the environmental conditions of southern Spain, where the soils for this study were collected. For this reason, the use of alternative materials to peat, such as biochar, for the restoration of degraded areas is essential for carbon sequestration and the struggle against climate change.

The lack of soil productivity can be considered a soil degradation process. In the case of soils from mining areas, the problem involves high concentrations of toxic compounds, particularly metals and metalloids. Metals can be found in nature, but their amounts do not exceed soil auto-depuration limits [3]; for that reason, the anthropogenic contribution is the main source of soil contamination. Mine tailings are classified as Technosols [4], which are soils altered by human activities [5]. In general, mining activities result in a low organic matter content and erosion, leading to poor soil quality, among others negative impacts [6-8]. 
The poor soil quality in soils from mining areas limits the growth of a vegetative plant cover. This cover would lead to the improvement of the soil's physical, chemical and biological properties. Soil biochemical properties (microbial structure, basal respiration, $\mathrm{C}$ and $\mathrm{N}$ mineralization, microbial biomass and enzyme activity) can be used as early indicators of changes in soil quality as they are more sensitive to alterations in management than soil's physical or chemical properties [9-11]. Indeed, the preservation of the soil biodiversity is a cornerstone for the performance of essential ecosystem services related to human wellbeing.

In order to assist revegetation, a number of amendments can be utilized. According to Spanish legislation, amendments comprise organic or inorganic materials that modify or improve soil properties [12]. In the case of organic amendments, the main objective is to maintain or increase organic matter content to improve soil's physical properties and the biological or chemical soil activity. Historically, organic manures have been used for plant nutrient supply [13], but nowadays, more modern approaches related to manure disposal are required [14]. The reuse of animal residues can generate added value and provide benefits to the soil, including a high amount of nutrients, organic matter and microbial activity as well as an increased plant yield [15]. In addition, manure waste can reduce metal mobility and bioavailability [15] due to the enhancement of, to some extent, geochemical processes (precipitation, sorption, ion exchange and redox reactions). The disadvantages of using manure waste are odor pollution, the contamination of soil and water bodies, and the presence of pathogens [16]. In that particular scenario, biochar production appears as an environmentally friendly solution in which the raw material (manure) can be transformed to a carbon-rich product that is easy to store and apply and comes with several benefits to soil quality [17-19].

Biochar is a solid material obtained from thermochemical conversion of biomass in an oxygen-limited environment [20]. Biochar is a carbon-rich product with several benefits: (i) increased soil productivity; (ii) positive influence on soil's physicochemical properties ( $\mathrm{pH}$, porosity, bulk density and water-holding capacity); (iii) increased soil fertility due to the biochar ash content; (iv) changes in soil microbial activity and nutrient cycling; (v) carbon storage [21-23]. In addition, several investigations have been performed with biochars from manure waste [22-24] and their potential to enhance plant growth. The addition of biochar to metal-contaminated soils can enhance plant yield, due to the reduction of bioavailable fractions of metals and the improvement of soil physical properties [25-31].

Different studies have shown the influence of biochar in the soil biochemical properties. A seminal work [32] studied the influence of sewage sludge biochar (pyrolysis temperature: $600{ }^{\circ} \mathrm{C}$ ) in an Umbrisol, describing contrasting results for different enzymatic activities. For example, dehydrogenase activity increased after the biochar addition while $\beta$-glucosidase decreased, and arylsulphatase activity was not affected by biochar addition. In addition, the application of biochar can improve the resistance of soil microbial properties to drought, which can have positives implications in the quality of restored soils [33]. For the particular case of degraded mine soils or metal multicontaminated soils, the addition of biochar to mining soils improves the nutrient and carbon availability, increasing the ratio $\mathrm{C} / \mathrm{N}$ as well as the soil water holding capacity, surface area and $\mathrm{pH}$ values; the reduction of bioavailability of toxic compounds produce changes in soil microorganism, improving the taxonomic diversity of the microorganism and recovering the soil microbiota structure [34]. For example, Tu et al. [35] concluded that the application of straw biochar (rate: 5\%) reduced the labile and bioavailable fraction of $\mathrm{Cu}$ and $\mathrm{Cd}$ and, at the same time, increased both catalase and urease activities; Wen et al. [36] observed, after the addition of wood biochar (rate: $3 \%$ ) in a contaminated paddy soil, a reduction in the available forms of As, $\mathrm{Cd}$ and $\mathrm{Pd}$ together with an increase in both catalase and urease activities. Gu et al. [31] emphasized the complexity of finding an overall trend of biochar on particular soil enzymes as each enzyme activity might reflect only a particular cellular function in response to the biochar amendment. For this reason, these authors [31] used the geometric mean (GMea) as an indicator of microbial enzymatic activities, concluding that the enzymatic activities of mine 
tailing did not increase after biochar addition. Indeed, the development of soil quality indices, including the geometric mean of enzyme activities, has been extensively used to study the biochar influence on soil quality [32,37]. In summary, soil biological properties have been studied due to their functions as indicators of soil quality, taking into account that soil microorganisms are more sensitive to contamination $[38,39]$, and variables, such as microbial biomass and enzyme activities, are an indirect measure of soil microbiota presence [40].

Plants from the Brassica genus have been used in the revegetation of mining areas as they tolerate high concentrations of metals. Brassica napus is an interesting species as it has the potential to accumulate $\mathrm{Cd}, \mathrm{Pb}$ and $\mathrm{Zn}$. Recently, in many countries, programs of renewable energy have started and acreage of rapeseed cultivation for biodiesel production is increasing. For this reason, industrial utilization of the rapeseed (Brassica napus) oil allows for the cultivation of this crop in polluted sites; thus, besides oil production, the simultaneous process of phytoremediation can be undertaken [41].

The combination of biochar and plant growth can improve soil biochemical properties and, therefore, enhance soil quality. For example, Lu et al. [42] observed an improvement on soil biochemical properties after the application of eucalyptus biochar $\left(600^{\circ} \mathrm{C}\right)$ and poultry litter biochar $\left(400^{\circ} \mathrm{C}\right)$ in a soil contaminated with $\mathrm{Cd}$ in the presence of Amaranthus tricolor $\mathrm{L}$. Briefly, they observed that microbial biomass and soil respiration were more $\mathrm{pH}$-dependent than soil enzymes. Recently, Alvarez et al. [37] concluded that, after the application of different manure waste biochars to 10 mining soils multicontaminated by trace metals, biochar can improve enzymatic activities in mining soils, reducing $\mathrm{CO}_{2}$ emissions by more than $28 \%$ in some cases and serving as an adequate strategy for $\mathrm{C}$ sequestration in soil.

With this background, we hypothesize that the application of biochar to metallic mining soils, combined with a plant cover, may have a positive effect on the improvement of the soil biological activity and can, therefore, be a promising alternative for the recovery of degraded mining areas [43]. The objective of this research is to study the influence of the combination of several amendments (biochar, rabbit manure and its combination) and the growth of Brassica napus on soil enzymes activities and soil microbial biomass in two mining soils of the Portman area (Spain). The Portman area is a well-known mining area in Spain $[43,44]$ with the presence of different mine tailings and soils with metals levels above the regulatory limits.

\section{Materials and Methods}

\subsection{Soil Selection}

The two soils (S1 and S2) were sampled from an area near a lead-zinc mine in Portman, Murcia close to La Unión and Cartagena (Spain). The sampling was made as follows: a similar amount of 30 subsamples (depth: $20 \mathrm{~cm}$ ) wase collected randomly in each area, and later, subsamples were mixed and homogenized. The soil S1 (Latitude: $37^{\circ} 35^{\prime} 23^{\prime \prime} \mathrm{N}$, Longitude: $0^{\circ} 51^{\prime} 38^{\prime \prime} \mathrm{W}$ ) is classified as a Technosol [4], being a mine tailing, and the soil S2 (Latitude: $37^{\circ} 35^{\prime} 22^{\prime \prime} \mathrm{N}$, Longitude: $0^{\circ} 51^{\prime} 54^{\prime \prime} \mathrm{W}$ ) is classified as a Cambisol [4], being the main minerals of the area sulphides (sphalerite, galena, pyrite), phyllosilicates and carbonates. Soils samples were air dried, crushed and passed through a $2 \mathrm{~mm}$ sieve.

\subsection{Manure Biochar Preparation}

The selected animal manure was rabbit manure (RM), obtained from the practice field of the Universidad Politécnica de Madrid (UPM, Madrid, Spain). RM was air-dried and passed through a $2 \mathrm{~mm}$ sieve. Two biochars were prepared from the pyrolysis of RM as raw material: $500 \mathrm{~g}$ of $\mathrm{RM}$ were introduced in a $2 \mathrm{~L}$ reactor made of steel. Samples were heated at $3{ }^{\circ} \mathrm{C} \mathrm{min}-1$ using an $\mathrm{N}_{2}$ flow of $0.5 \mathrm{~L} \mathrm{~min}^{-1}$ until 300 and $600{ }^{\circ} \mathrm{C}$, leading to $\mathrm{B} 300$ and $\mathrm{B} 600$, respectively. The final temperature was maintained during $1 \mathrm{~h}$. The reactor used for the pyrolysis was designed by Demede (http:/ / demede.es, accessed on 20 December 2021) with specifications for our research group. 


\subsection{Soils and Rabbit Manure and Biochars Characterization}

The $\mathrm{pH}$ and electrical conductivity (EC) of soils (S1 and S2) were measured with a Crison micro-pH 2000 and a Crison 222 conductivimeter, which weighed $10 \mathrm{~g}$ of the soil and $25 \mathrm{~mL}$ of distilled water. The cation exchange capacity (CEC) was determined with the cohex (hexaminecobalt III) method, according to a standardized protocol ISO 23,470 [45]. This procedure was also used to measure the exchangeable $\mathrm{K}^{+}$in the solution with a Perkin Elmer Analyst 400 Atomic Absorption Spectrophotometer. The oxidizable organic carbon $\left(\mathrm{C}_{\text {oxi }}\right)$ was calculated using the Walkley-Black method [46], and the available phosphorus (P) was determined by the Olsen method [47]. The total content in the $\mathrm{Cd}, \mathrm{Cu}, \mathrm{Zn}, \mathrm{As}, \mathrm{Pb}$ and $\mathrm{Zn}$ was determined using an Inductively Coupled Plasma Mass Spectrometry (ICP-MS) after the sample digestion with $3 \mathrm{~mL}$ of concentrated $\mathrm{HCl}$ and $1 \mathrm{~mL}$ of $\mathrm{HNO}_{3}$ following the USEPA 3051a method [48].

For the RM, B300 and B600, the $\mathrm{pH}$ and EC were measured with the same aforementioned equipment but with a ratio of $4 \mathrm{~g} \mathrm{~L}^{-1}\left(\mathrm{H}_{2} \mathrm{O}\right)$. The $\mathrm{C}_{\text {oxi }}, \mathrm{CEC}, \mathrm{P}$, exchangeable $\mathrm{K}^{+}$ and metal content were determined with the different process previously explained for soils. In addition, the proximate analysis and elemental analysis were performed for the amendments. The proximate analysis was determined using a thermogravimetric analyzer TGA Labsys Setaram, where $20 \mathrm{mg}$ of the amendments were heated at a rate of $20{ }^{\circ} \mathrm{C} \mathrm{min}-1$ until $600{ }^{\circ} \mathrm{C}$ under an $\mathrm{N}_{2}$ atmosphere at a flux of $40 \mathrm{~mL} \mathrm{~min}^{-1}$; at this point, an air atmosphere was introduced until there was a constant weight. The range of temperatures between 30 and $150{ }^{\circ} \mathrm{C}$ involve the moisture loss and 150 to $600{ }^{\circ} \mathrm{C}$ correspond to the volatile matter content (VM); the final loss was related to ash and the fixed carbon (FC) content was calculated by the difference. The elemental analysis (C, H, N and S) was determined by dry combustion using a LECO CHNS 932 Analyzer, and oxygen $(\mathrm{O})$ was obtained by the following calculation: $100 \%-(\mathrm{C}+\mathrm{H}+\mathrm{N}+\mathrm{S}+$ Ash $)$.

\subsection{Experimental Design}

Two soils (S1 and S2) were amended at a rate of $10 \%(w / w)$ with five amendments: (1) RM, (2) B300, (3) B600, (4) B300+RM and (5) B600 + RM. The last two amendments were the combination of $50 \%$ of the corresponding biochar with the $50 \%$ of RM. Amended soils were introduced in pots (volume of $500 \mathrm{~mL}$ ). The control soils corresponded to (1) both soils without amendments (S1, S2) and (2) the amendments soils without plant growth. For each pot, the mesocosms were filled first with a gravel layer $(100 \mathrm{~g})$, followed by $300 \mathrm{~g}$ of the respective mixture. In half of the mesocosms, 10 seeds of Brassica napus were sown in the surface layer. Then, pots were introduced in an incubator with light cycles every $12 \mathrm{~h}$ at a controlled temperature of 20 to $25^{\circ} \mathrm{C}$ for 45 days. Each treatment was weighed for an initial weight, which was replenished daily by the addition of an equivalent mass of distilled water. All treatments were undertaken in triplicate.

In summary, for both soils, treatments were labelled as S1, S1 + B300, S1 + B600, $\mathrm{S} 1+\mathrm{B} 300+\mathrm{RM}, \mathrm{S} 1+\mathrm{B} 600+\mathrm{RM}$ and S1 + RM and as S2, S2 + B300, S2 + B600, S2 + B300 + RM, $\mathrm{S} 2+\mathrm{B} 600+\mathrm{RM}$ and $\mathrm{S} 2+\mathrm{RM}$.

\subsection{Soil Enzyme Activities and Microbial Biomass Measurements}

Dehydrogenase, phosphomonoesterase and $\beta$-glucosidase activities were determined after 45 days of incubation. The geometric mean (GMea) index was calculated as a suitable measure of soil biochemical activity that integrated the abovementioned enzymes [32]. For dehydrogenase activity, 2-(p-iodophenyl)-3-(p-nitrophenyl)-5-phenyltetrazolium chloride (INT) was used as the substrate, and the activity of the enzyme was expressed in $\mu$ mol INTF $g^{-1} h^{-1}$. Phosphomonoesterase and $\beta$-glucosidase were determined after incubating soils with a substrate containing a p-nitrophenyl moiety, and then, in the enzymatic hydrolysis, the amount of released p-nitrophenol was measured. Both enzymes were expressed as $\mu$ mol p-nitrophenol $\mathrm{g}^{-1} \mathrm{~h}^{-1}$ [32]. The GMea offers unifying information from variables that possess different units and range of variation, and it has been established as an adequate index for estimating soil biochemical quality after the addition 
of different amendments, including biochar, as follows: GMea = (phosphomonoesterase $x \beta$-glucosidase $\times$ dehydrogenase $)^{1 / 3}$ [39]. Soil microbial biomass (SMB) was assessed by the difference between the carbon content of the fumigated and unfumigated samples (following chloroform fumigation-extraction method) with a commonly used factor $(\mathrm{Kc}=0.45)$ for soils amended with organic materials [49].

\subsection{Statistical Analysis}

The significance of the differences among means was assessed by analysis of variance (ANOVA). Duncan's multiple range test $(p<0.05)$ was implemented using the Statgraphics Centurion XVI.I. software for the calculations. Every analysis was performed in triplicate.

\section{Results and Discussion}

\subsection{Soils and Amendments Characterization}

Table 1 summarized the physicochemical properties of both soils (S1 and S2), rabbit manure (RM) and the 2 biochars (B300 and B600) soils. The soils had alkaline pH values showing different electrical conductivity (EC). For S1, the EC was 2200; meanwhile, for S2, the EC was $300 \mu \mathrm{S} \mathrm{cm}{ }^{-1}$. For both soils, the oxidizable organic carbon $\left(\mathrm{C}_{\text {oxi }}\right)$ was under $1 \%$, which underscores the importance of performing an organic amendment in order to increase soil productivity. The cation exchange capacity (CEC) did not present significant differences between the two soils, and the bioavailable P content was an order of magnitude higher in S2 compared to S1. The two selected soils had a sandy loam texture. Both soils (Table 1) exceeded the critical soil metal concentration, indicating that toxic effects are likely, which are 3-8 $\mathrm{mg} \mathrm{kg}^{-1}$ for Cd, 20-50 $\mathrm{mg} \mathrm{kg}^{-1}$ for As, 100-400 for Pb and 70-400 for Zn, according to [50]. Furthermore, S2 soil had a $\mathrm{Cu}$ soil content higher than the critical soil value $\left(60-125 \mathrm{mg} \mathrm{kg}^{-1}\right)$ [50].

Table 1. Chemical and physical properties of soils, rabbit manure (RM) and biochars (B300 and B600).

\begin{tabular}{|c|c|c|c|c|c|}
\hline & S1 & S2 & RM & B300 & B600 \\
\hline $\mathrm{pH}$ & $7.9 \mathrm{a}^{1}$ & $8.1 \mathrm{~b}$ & $9.2 \mathrm{c}$ & $8.6 \mathrm{~d}$ & $10.8 \mathrm{e}$ \\
\hline $\mathrm{EC}\left(\mu \mathrm{S} \mathrm{cm}^{-1} 20^{\circ} \mathrm{C}\right)$ & $2200 \mathrm{a}$ & $300 \mathrm{~b}$ & $620 c$ & $340 \mathrm{~b}$ & $390 \mathrm{~b}$ \\
\hline $\mathrm{C}_{\mathrm{oxi}}(\%)$ & $0.3 \mathrm{a}$ & $0.9 \mathrm{~b}$ & $20.1 \mathrm{c}$ & $20.4 \mathrm{c}$ & $5.1 \mathrm{~d}$ \\
\hline $\mathrm{CEC}\left(\mathrm{cmol}_{\mathrm{C}} \mathrm{kg}^{-1}\right)$ & $10.6 \mathrm{a}$ & $12.2 \mathrm{a}$ & $99 c$ & $146 \mathrm{~d}$ & $127 \mathrm{e}$ \\
\hline $\mathrm{P}\left(\mathrm{mg} \mathrm{kg}^{-1}\right)$ & $722 \mathrm{a}$ & $6632 \mathrm{~b}$ & $4700 \mathrm{c}$ & $1600 \mathrm{~d}$ & $800 \mathrm{e}$ \\
\hline $\mathrm{Fe}\left(\mathrm{g} \mathrm{kg}^{-1}\right)$ & $185 \mathrm{a}$ & $113 \mathrm{a}$ & $3.4 \mathrm{~b}$ & $2.8 \mathrm{~b}$ & $5.2 \mathrm{c}$ \\
\hline $\mathrm{Cd}\left(\mathrm{mg} \mathrm{kg}^{-1}\right)$ & $16 \mathrm{a}$ & $20 \mathrm{a}$ & $0.31 \mathrm{~b}$ & $0.30 \mathrm{~b}$ & $0.39 c$ \\
\hline $\mathrm{Cu}\left(\mathrm{mg} \mathrm{kg}^{-1}\right)$ & $47 \mathrm{a}$ & $207 \mathrm{~b}$ & $69 c$ & $82 \mathrm{~d}$ & 90 e \\
\hline As $\left(\mathrm{mg} \mathrm{kg}^{-1}\right)$ & $530 \mathrm{a}$ & $1183 \mathrm{~b}$ & $1.7 \mathrm{c}$ & $1.6 \mathrm{c}$ & $1.6 \mathrm{c}$ \\
\hline $\mathrm{Pb}\left(\mathrm{mg} \mathrm{kg}^{-1}\right)$ & $2770 \mathrm{a}$ & $2848 \mathrm{~b}$ & $7.8 \mathrm{c}$ & $5.4 \mathrm{~d}$ & $7.6 \mathrm{c}$ \\
\hline $\mathrm{Zn}\left(\mathrm{mg} \mathrm{kg}^{-1}\right)$ & 6373 a & $8573 \mathrm{~b}$ & $675 c$ & $924 \mathrm{~d}$ & $1008 \mathrm{~d}$ \\
\hline Ash (\%) & - & - & 40.1 & 50.6 & 61.4 \\
\hline VM (\%) & - & - & 38.8 & 30.1 & 4.9 \\
\hline FC $(\%)$ & - & - & 19.5 & 19.4 & 33.7 \\
\hline Ratio FC/(VM + FC) & - & - & 0.33 & 0.39 & 0.87 \\
\hline$C(\%)$ & - & - & 20.1 & 31.3 & 29.6 \\
\hline $\mathrm{H}(\%)$ & - & - & 3.1 & 3.3 & 1.3 \\
\hline $\mathrm{N}(\%)$ & - & - & 1.9 & 2.1 & 0.8 \\
\hline $\mathrm{S}(\%)$ & - & - & 0.3 & 0.5 & 0.4 \\
\hline $\mathrm{O}(\%)$ & - & - & 33.9 & 12.1 & 6.5 \\
\hline $\mathrm{H} / \mathrm{C}$ & - & - & 1.85 & 1.26 & 0.53 \\
\hline $\mathrm{O} / \mathrm{C}$ & - & - & 1.26 & 0.29 & 0.16 \\
\hline
\end{tabular}

${ }^{1}$ Values followed by the same letter are not significantly different $(p=0.05)$ using Duncan's test.

All the amendments (RM, B300 and B600) showed alkaline pH, but there was a variation in the $\mathrm{pH}$ after the $\mathrm{RM}$ pyrolysis, where the $\mathrm{B} 300$ had a lower $\mathrm{pH}$ value compared to the $\mathrm{RM}$, and the $\mathrm{B} 600$ had a higher $\mathrm{pH}$ value. In this case, the pyrolysis temperature played an important role. According to Al-Wabel et al. [51], the $\mathrm{pH}$ decrease with a lower 
temperature of production is explained by the separation of alkaline salts and organic materials. The electrical conductivity (EC) values were lower and similar in the biochars compared with the RM. The $\mathrm{C}_{\text {oxi }}$ content of $\mathrm{B} 600$ was the lowest $(5.13 \%)$ while the $\mathrm{C}_{\text {oxi }}$ content of the RM and B300 exceeded $20 \%$. The carbon structure changes with the pyrolysis temperature, and at higher temperatures, the carbon structure is more aromatic with lower $\mathrm{H} / \mathrm{C}$ ratios [52]. Indeed, the H/C ratio decreased from 1.85 (RM) to 1.26 (B300) and 0.53 (B600) after pyrolysis. CEC increased between 28\% (B600) and 47\% (B300) after pyrolysis, similar to the results of Gaskin et al. [53], who found higher CEC for biochars obtained by pyrolysis at low temperatures. The available $\mathrm{P}$ in biochar decreased when compared to the raw material (RM), reducing the risk of nutrient leaching and, therefore, of groundwater contamination. The ash content in biochars was at least $10 \%$ greater than raw material due to ash concentration during pyrolysis. The proximate analysis showed that volatile matter (VM) diminished with the pyrolysis temperature reaching values $87 \%$ lower than raw material at $600{ }^{\circ} \mathrm{C}$, similar to the results found by other authors [21]. According to this data, the fixed carbon (FC) content increased by $14.2 \%$ after pyrolysis at $600{ }^{\circ} \mathrm{C}$.

The elemental analysis of the samples was also included in Table 1 . The percentage of $C$ increased in the biochars, with respect to RM, and the lowest values of $H, N$ and $\mathrm{O}$ were found in $\mathrm{B} 600$. The volatilization process of light compounds that take place during pyrolysis could explain these results. For example, some of the $\mathrm{N}$ functional groups are stable at low pyrolysis temperatures and recalcitrant to degradation but can be decomposed at the highest temperature used in our experiment [53]. Dehydration and condensation reactions are also involved in the decrease of $\mathrm{O}$ and $\mathrm{H}$ content due to the reduction process of $\mathrm{O}$ functional groups after pyrolysis [54]. Consequently, the $\mathrm{O} / \mathrm{C}$ and $\mathrm{H} / \mathrm{C}$ ratios significantly decreased with the pyrolysis temperature due to the influence of the pyrolysis temperature in the aromatic structure of biochars [55]. The metal content of the rabbit manure and biochars (B300 and B600) did not exceed the limits of Spanish legislation for their use as fertilizers [12]. In comparison to the legislation on the use of sewage sludge in soils [56], the metals concentration was below the threshold in most cases $(\mathrm{Cd}, \mathrm{Cu}, \mathrm{Pb}$ and $\mathrm{As})$, except in the case of $\mathrm{Zn}$ where the content of $\mathrm{RM}$ and biochars were higher than Spanish regulatory levels (150-450 $\mathrm{mg} \mathrm{kg}^{-1}$ ).

\subsection{Soil Enzyme Activities and Soil Microbial Biomass (SMB)}

The effect of the different amendments and Brassica napus growth on biochemical properties was evaluated by phosphomonoesterase, $\beta$-glucosidase and dehydrogenase activities (Figure 1). For S1 soil, the addition of RM, B300 + RM and B600 + RM increased phosphomonoesterase activity while the addition of $\mathrm{B} 600$ biochar reduced the value of this enzymatic activity below control soil values (S1). For S2 soil, there was a similar trend, with the addition of B300 biochar resulting in an increase in phosphomonoesterase activity. In general, the presence of Brassica napus did not change the behavior of phosphomonoesterase, in accordance with previous studies [57]. The highest value of this enzyme activity was reached with the RM and B300 + RM treatment, which could be related to the higher amounts of available P supplied by the B300 and B300 + RM treatments. Indeed, the $\mathrm{P}$ availability of $\mathrm{B} 600$ biochar decreased by $83.8 \%$ with respect to rabbit manure. Similar results were found by Liang et al. [33], who observed the lowest values of phosphomonoesterase activity in soils amended with poultry litter biochar produced at $600{ }^{\circ} \mathrm{C}$ while the addition of biochar prepared at $400^{\circ} \mathrm{C}$ improved this enzyme. For soil S1, $\beta$-glucosidase (Figure 2) increased in the treatments B300, B300 + RM and RM and also after the addition of the B600 + RM amendment combined with the presence of Brassica napus. For soil S2, the presence of Brassica napus had an influence in the increment of this enzyme after the application of all amendments. Variations in enzymes, such as $\beta$-glucosidase, degrading major soil organic matter components can be related to changes in the decomposition rate, mediated by changes in substrate availability. Therefore, the different results obtained for the $\beta$-glucosidase can be related to the presence of fresh organic matter supplied by the plants and the higher content of volatile matter (VM) and, therefore, the labile carbon 
of the RM and B300 with respect to the B600. Indeed, the VM content of the B600 was reduced $74.5 \%$ after pyrolysis at $600{ }^{\circ} \mathrm{C}$. Some investigations $[33,58]$ demonstrated that $\beta$-glucosidase activity diminished with biochars prepared at $500{ }^{\circ} \mathrm{C}$, which is the pyrolysis temperature; this is a key factor related to the behavior of this enzyme activity. Finally, for both soils, dehydrogenase activity involved in soil respiration was improved for all treatments except for the addition of the B600 to S1 soil due to the addition of the labile organic matter. This was in agreement with previous studies, which recorded an increase of this activity related to an increase in carbon substrate and improvements in soil aeration and soil $\mathrm{pH}$ associated with biochar use $[57,59]$. The low values obtained in $\beta$-glucosidase and dehydrogenase activities after the application of the B600 biochar are likely a consequence of its more aromatic carbon structure, compared to the biochar obtained by pyrolysis at $300{ }^{\circ} \mathrm{C}$. Higher temperatures imply a more stable carbon material, making it more difficult for the microorganisms to use the $\mathrm{C}$ content as a source of energy [59]. On the contrary, the $C$ structure for the biochars obtained at lower temperatures show a more aliphatic structure, which is more available for soil microbiota. A way to measure this particular result is the volatile matter (VM) and fixed carbon (FC) content of the materials, where a high VM content is related to light $\mathrm{C}$ structures, and high $\mathrm{FC}$ content is linked to more aromatic and stable $\mathrm{C}$ structures. The VM content of the $\mathrm{B} 600$ was $4.93 \%$ while the $\mathrm{B} 300$ and $\mathrm{RM}$ had contents around $30 \%$, according to the oxidizable organic carbon content $\left(\mathrm{C}_{\text {oxi }}\right)$.

The obtained results are similar to the conclusions of other investigations. For example, Liang et al. [33] also reported the decrease of the phosphomonoesterase activity with the addition of the poultry litter biochar produced at $600^{\circ} \mathrm{C}$ whereas the activity increased with the soils amended with the biochar at $400{ }^{\circ} \mathrm{C}$. In the case of the $\beta$-glucosidase activity, the lowest values were found with biochars obtained at $600^{\circ} \mathrm{C}$ while it has been reported that biochars produced by pyrolysis at $350^{\circ} \mathrm{C}$ improved dehydrogenase activity $[58,59]$.

Nevertheless, it is not easy to obtain a general conclusion about the effect of the different treatments in a specific enzyme, due to the many properties involved in the regulation of soil enzyme activities. For this reason, the GMea index has been used several times to study the influence of biochar in soil quality. For example, Paz-Ferreiro et al. [32] used this index to study the influence of biosolids biochar in an Umbrisol and Lu et al. [38] to evaluate the soil quality in a soil contaminated with $\mathrm{Cd}$ after the addition of poultry litter and eucalyptus biochars. More recently, Cárdenas-Aguiar et al. [57] used the GMea index to study the changes in the soil quality of two mining soils after treatment with biochar and hydrochar prepared from different manures. For the S1 soil, the amendments B300, B300 + RM, B600 + RM and RM increased soil biological activity, with the best result obtained with the application of rabbit manure (RM) without Brassica napus. For S2 soil, all amendments, except the addition of biochar B600, improved the GMea index with the highest results being obtained by rabbit manure (RM) (with or without plants) and the mixture of biochar B300 and rabbit manure (RM) with Brassica napus. 

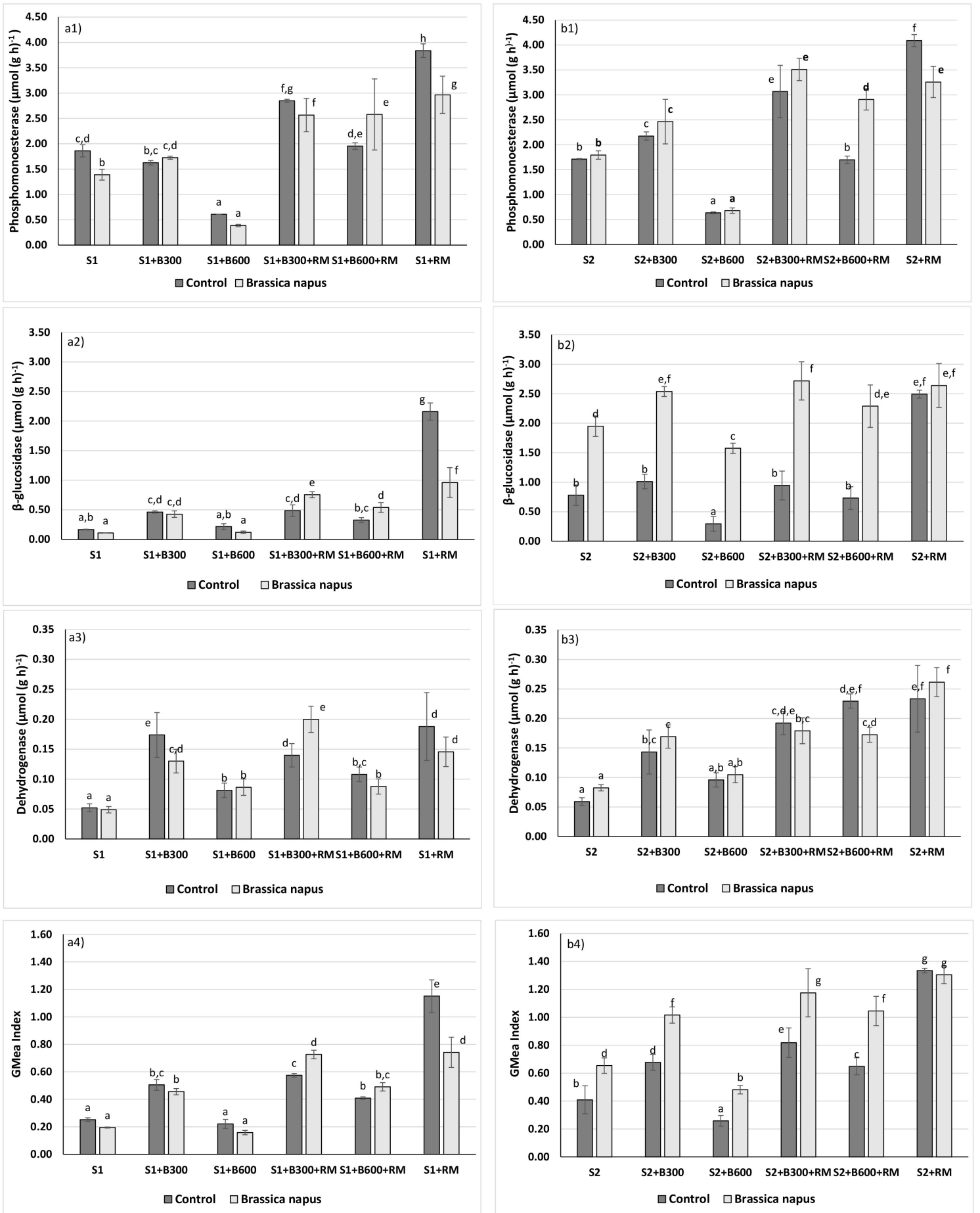

Figure 1. (a1) phosphomonoesterase activity $\left(\mu \mathrm{mol}(\mathrm{g} \cdot \mathrm{h})^{-1}\right)$ for $\mathrm{S} 1$ soil, (a2) $\beta$-glucosidase activity $\left(\mu \mathrm{mol}(\mathrm{g} \cdot \mathrm{h})^{-1}\right)$ for S1 soil, (a3) dehydrogenase activity $\left(\mu \mathrm{mol}(\mathrm{g} \cdot \mathrm{h})^{-1}\right.$ ) for S1 soil, (a4) GMea index for S1 soil, (b1) phosphomonoesterase activity $\left(\mu \mathrm{mol}(\mathrm{g} \cdot \mathrm{h})^{-1}\right)$ for S2 soil, (b2) $\beta$-glucosidase activity $\left(\mu \mathrm{mol}(\mathrm{g} \cdot \mathrm{h})^{-1}\right)$ for S2 soil, (b3) dehydrogenase activity $\left(\mu \mathrm{mol}(\mathrm{g} \cdot \mathrm{h})^{-1}\right)$ for S2 soil, (b4) GMea index for S2 soil. Values followed by the same letter are not significantly different $(p=0.05)$ using Duncan's test. The differences were made between soils and enzymes. 


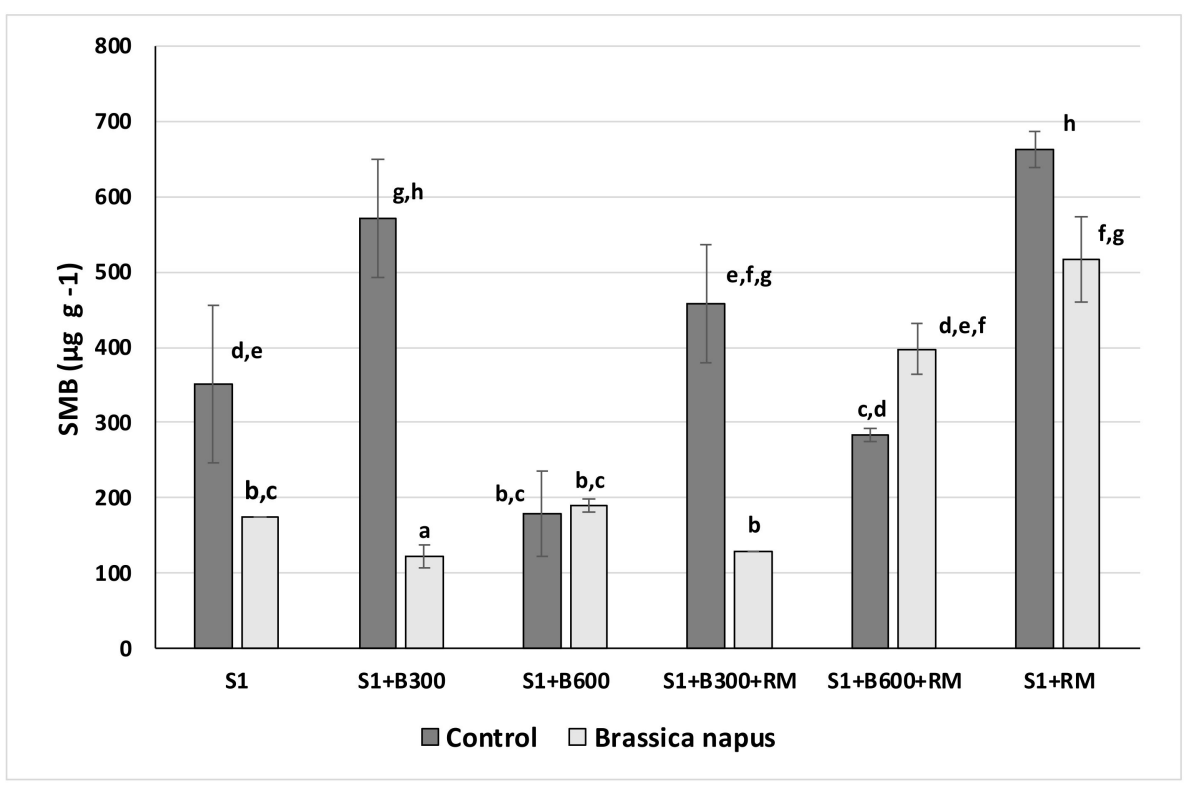

(a)

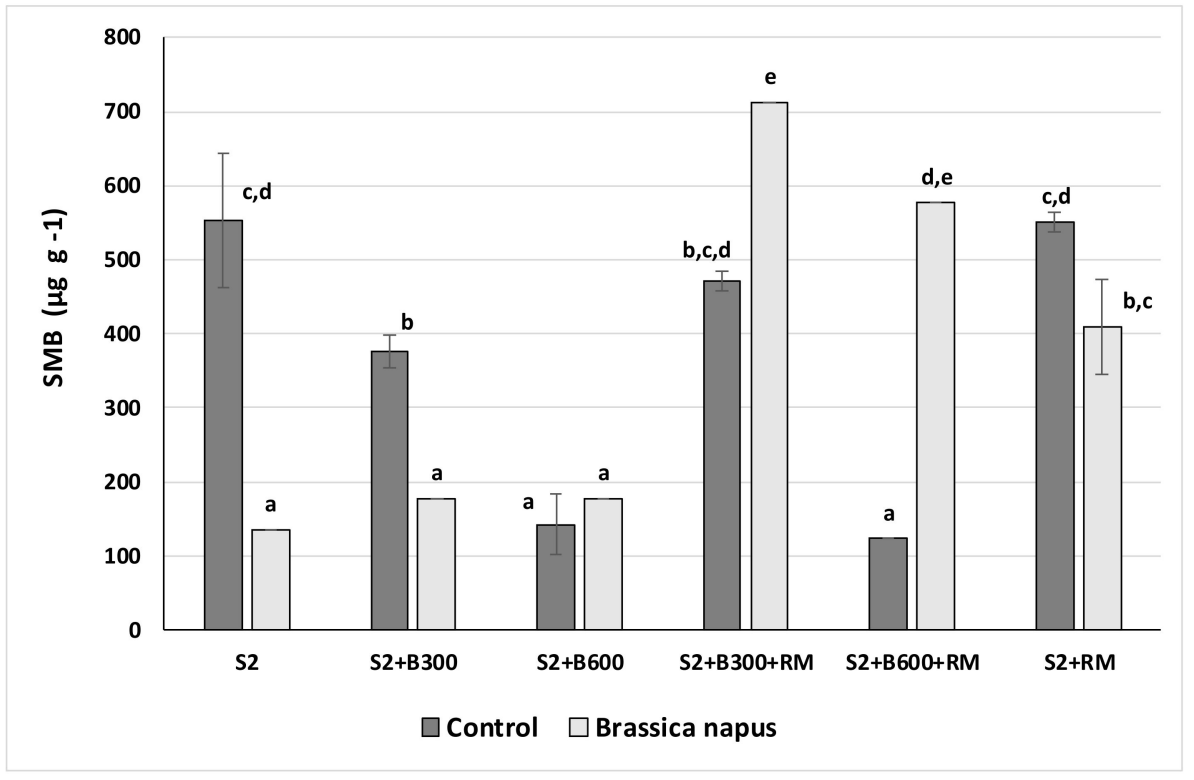

(b)

Figure 2. SMB $\left(\mu \mathrm{g} \mathrm{g}^{-1}\right)$ for Brassica napus treatments and the respective control soils: (a) S1 soil and (b) S2 soil. Values followed by the same letter are not significantly different $(p=0.05)$ using Duncan's test.

For the GMea, as a general behavior, the following results were found: (i) the addition of rabbit manure (RM) to both soils enhanced soil biochemical properties leading to the highest values; (ii) the amendments B300, B300 + RM and B600 + RM improved soil biological activities; (iii) the mixture of rabbit manure (RM) and biochar produced at $600{ }^{\circ} \mathrm{C}$ (B600) improved the properties of B600 and increased the GMea index; (iv) the growth of Brassica napus had a positive effect on enzyme activities, with respect to the treatments without plants, when it was combined with B300 + RM in the soil S1 and with B300, B600, $\mathrm{B} 300$ + RM and B600 + RM for S2 soil. These last results differed from Cárdenas et al. [57], who observed a decrement on the GMea index in different mining soils in the presence of Brassica Napus after the application of rabbit manure biochars (pyrolysis temperature: $450{ }^{\circ} \mathrm{C}$ and $600{ }^{\circ} \mathrm{C}$ ) and hydrochars (hydrothermal carbonisation temperature: $190{ }^{\circ} \mathrm{C}$ and $240{ }^{\circ} \mathrm{C}$ ) in a metal multicontaminated soil. Nevertheless, the improvement of the 
GMea index when biochar is combined with plants has been previously described by Lu et al. [38] using Amaranthus combined with poultry litter. These authors attributed part of this improvement in biochemical properties to a possible immobilization of trace metals in soils after the application of biochar or other organic amendments.

Finally, the higher content of labile carbon content $\left(\mathrm{C}_{\text {oxi }}\right)$, volatile matter $(\mathrm{VM})$, bioavailable $\mathrm{P}$ of rabbit manure (RM) and B300 could be the reason for the improvement of the overall enzyme activity (GMea index) when this amendment, alone or combined, is added to soils.

Figure 2 shows the SMB for soils with and without Brassica napus growth. The microbial biomass is related to the enzyme activities because phosphomonoesterase, $\beta$-glucosidase and dehydrogenase act on the substrates used by microorganisms to grow. SMB can provide insight on the long-term trajectory of soil organic matter dynamics. As discussed in Section 3.1, the carbon skeleton of the amendments was vastly different. In general, soils presented more SMB when a more labile form of carbon (RM > B300 > B600), which is more accessible to the microorganisms, was added. In particular, for the soil S1, the best results were obtained from the application of B300 and rabbit manure (RM) without Brassica napus while for the soil S2, higher values were obtained from the mixture of B300 and RM in the presence of Brassica napus. The presence of Brassica napus reduced the soil microbial biomass (SMB) in both control soils (S1 and S2). This fact was previously described by Cárdenas et al. [58] in two mining soils with a similar basic pH although Gascó et al. [60] did not observe any negative effect with the presence of Brassica napus in a mining soil with a $\mathrm{pH}$ of 4.3 . The addition of the different amendments, combined with the presence of Brassica napus, had a diverse effect on the SMB, depending on soil. Indeed, only the addition of the B300 had a negative effect on the SMB, probably due to the phytotoxicity of the biochar B300 previously described by [61].

\section{Conclusions}

In general, we found that the choice of amendment was more important that the presence or absence of vegetative cover for increasing soil biological properties. The presence of Brassica could have other long-term benefits, including immobilizing heavy metals, mitigating soil erosion and providing a feedstock for fuel, which were not evaluated here. There tended to be consistency in the best performing amendments across both soils. The overall enzyme activity reached the higher values after the application of rabbit manure to both soils (Cambisols and Technosols). Furthermore, the mixture of rabbit manure with biochar prepared at 300 and $600{ }^{\circ} \mathrm{C}$ improved the soil biochemical activities with respect to the sole application of biochars. Moreover, the effect of the combination of the amendments and Brassica napus on biochemical properties depends on soil type and whether or not the amendment effect is enzyme-specific. In summary, (i) the application of rabbit manure, rabbit manure biochar prepared at $300{ }^{\circ} \mathrm{C}$ or the application of mixtures of rabbit manure with biochars prepared at $300 / 600{ }^{\circ} \mathrm{C}$ can improve the soil quality of degraded areas by mining activities and serve as an adequate technique for soil remediation; (ii) the use of biochar prepared at low temperatures for soil remediation could be a promising research direction to reduce the economic cost of the thermal treatment, while contributing to soil carbon sequestration.

Author Contributions: E.C.-A., J.P.-F., A.M. and G.G. conceived the experiment, collected and analyzed the data and wrote the article. All authors have read and agreed to the published version of the manuscript.

Funding: This research was funded by Economy and Competitiveness Ministry of Spain, grant number CGL2014-58322-R.

Institutional Review Board Statement: Not applicable.

Informed Consent Statement: Not applicable.

Data Availability Statement: Not applicable. 
Conflicts of Interest: The authors declare no conflict of interest.

\section{References}

1. Breure, A.M.; Lijzen, J.P.A.; Maring, L. Soil and land management in a circular economy. Sci. Total Environ. 2018, 624, 1125-1130. [CrossRef] [PubMed]

2. Hillel, D.; Rosenzweig, C. The Role of Soils in Climate Change. In Handbook of Climate Change and Agroecosystems: Impacts, Adaptation, and Mitigation; Hillel, D., Rosenzweig, C., Eds.; Imperial College Press: London, UK, 2010; pp. 9-20.

3. Jímenez- Ballesta, R. Introducción a la Contaminación de Suelos; Mundi-Prensa: Madrid, Spain, 2017; pp. 1-34.

4. Food and Agriculture Organization of the United Nations; IUSS Working Group WRB. World Reference Base for Soil Resources 2014, Update 2015: International Soil Classification System for Naming Soils and Creating Legends for Soil Maps; World Soil Resources Reports No. 106; Food and Agriculture Organization of the United Nations: Rome, Italy, 2015.

5. Blum, W.E.H.; Schad, P.; Nortcliff, S. Essentials of Soil Science: Soil Formation, Functions, Use and Classification (World Reference Base, WRB); Borntraeger Science Publihser: Stuttgart, Germany, 2018.

6. Li, X.; Wang, X.; Chen, Y.; Yang, X.; Cui, Z. Optimization of combined phytoremediation for heavy metal contaminated mine tailings by a field-scale orthogonal experiment. Ecotoxicol. Environ. Saf. 2019, 168, 1-8. [CrossRef] [PubMed]

7. Liu, L.; Li, W.; Song, W.; Guo, M. Remediation techniques for heavy metal-contaminated soils: Principles and applicability. Sci. Total Environ. 2018, 633, 206-219. [CrossRef] [PubMed]

8. Puga, A.P.; Melo, L.C.A.; de Abreu, C.A.; Coscione, A.R.; Paz-Ferreiro, J. Leaching and fractionation of heavy metals in mining soils amended with biochar. Soil Tillage Res. 2016, 164, 25-33. [CrossRef]

9. Lu, H.; Li, Z.; Fu, S.; Méndez, A.; Gascó, G.; Paz-Ferreiro, J. Effect of Biochar in Cadmium Availability and Soil Biological Activity in an Anthrosol Following Acid Rain Deposition and Aging. Water Air Soil Pollut. 2015, 226, 164. [CrossRef]

10. Nannipieri, P.; Kandeler, E.; Ruggiero, P. Enzyme Activities and Microbiological and Biochemical Processes in Soil. In Enzymes in the Environment. Activity, Ecology and Applications; Burns, R.G., Dick, R.P., Eds.; Marcel Dekker: New York, NY, USA, 2002; pp. 1-33.

11. Paz-Ferreiro, J.; Trasar-Cepeda, C.; Leirós, M.C.; Seoane, S.; Gil-Sotres, F. Biochemical properties in managed grassland soils in a temperate humid zone: Modifications of soil quality as a consequence of intensive grassland use. Biol. Fertil. Soils 2009, 45, 711-722. [CrossRef]

12. Ministerio de la Presidencia. Real decreto 506/2013, de 28 de junio, sobre productos fertilizantes. Bol. Off. Estado 2013, 164, 51119-51207.

13. Haynes, R.J.; Naidu, R. Influence of lime, fertilizer and manure applications on soil organic matter content and soil physical conditions: A review. Nutr. Cycl. Agroecosyst. 1998, 51, 123-137. [CrossRef]

14. Song, C.; Shan, S.; Müller, K.; Wu, S.; Niazi, N.K.; Xu, S.; Shen, Y.; Rinklebe, J.; Liu, D.; Wang, H. Characterization of pig manure-derived hydrochars for their potential application as fertilizer. Environ. Sci. Pollut. Res. 2017, 25, 25772-25779. [CrossRef]

15. Rodríguez-Vila, A.; Covelo, E.F.; Forján, R.; Asensio, V. Phytoremediating a copper mine soil with Brassica juncea L., compost and biochar. Environ. Sci. Pollut. Res. 2014, 21, 11293-11304. [CrossRef] [PubMed]

16. Cárdenas-Aguiar, E.; Gascó, G.; Paz-Ferreiro, J.; Méndez, A. Thermogravimetric analysis and carbon stability of chars produced from slow pyrolysis and hydrothermal carbonization of manure waste. J. Anal. Appl. Pyrolysis 2019, 140, 434-443. [CrossRef]

17. Paz-Ferreiro, J.; Fu, S.; Méndez, A.; Gascó, G. Interactive effects of biochar and the earthworm Pontoscolex corethrurus on plant productivity and soil enzyme activities. J. Soils Sediments 2014, 14, 483-494. [CrossRef]

18. Lehmann, J.; Joseph, S. Biochar for Environmental Management; Earthscan: London, UK, 2009; pp. 1-12.

19. Spokas, K.A.; Cantrell, K.B.; Novak, J.M.; Archer, D.W.; Ippolito, J.A.; Collins, H.P.; Boateng, A.A.; Lima, I.M.; Lamb, M.C.; McAloon, A.J.; et al. Biochar: A synthesis of its agronomic impact beyond carbon sequestration. J. Environ. Qual. 2012, 41, 973-989. [CrossRef] [PubMed]

20. International Biochar Initiative. Standardized Product Definition and Product Testing Guidelines for Biochar that Is Used in Soil; International Biochar Initiative: Canadaigua, NY, USA, 2015.

21. Cely, P.; Gascó, G.; Paz-Ferreiro, J.; Méndez, A. Agronomic properties of biochars from different manure wastes. J. Anal. Appl. Pyrolysis 2015, 111, 173-182. [CrossRef]

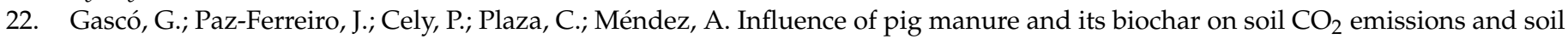
enzymes. Ecol. Eng. 2016, 95, 19-24. [CrossRef]

23. Zornoza, R.; Acosta, J.A.; Faz, A.; Bååth, E. Microbial growth and community structure in acid mine soils after addition of different amendments for soil reclamation. Geoderma 2016, 272, 64-72. [CrossRef]

24. Liu, Y.; Yao, S.; Wang, Y.; Lu, H.; Brar, S.K.; Yang, S. Bio- and hydrochars from rice straw and pig manure: Inter-comparison. Bioresour. Technol. 2017, 235, 332-337. [CrossRef]

25. Manzano, R.; Diquattro, S.; Roggero, P.P.; Pinna, M.V.; Garau, G.; Cataldi, P. Addition of softwood biochar to contaminated soils decreases the mobility, leachability and bioaccesibility of potentially toxic elements. Sci. Total Environ. 2020, $739,139946$. [CrossRef]

26. Munir, M.A.M.; Irshad, S.; Yousaf, B.; Ali, M.U.; Dan, C.; Abbas, Q.; Liu, G.; Yang, X. Interactive assessment of lignite and bamboo-biochar for geochemical speciation, modulation and uptake of $\mathrm{Cu}$ and other heavy metals in the copper mine tailing. Sci. Total Environ. 2021, 779, 145536. [CrossRef] 
27. Chen, Y.; Xu, J.; Lv, Z.; Xie, R.; Huang, L.; Jiang, J. Impacts of biochar and oyster shells waste on the immobilization of arsenic in highly contaminated soils. J. Environ. Manag. 2018, 217, 646-653. [CrossRef]

28. Lu, H.P.; Li, Z.A.; Gascó, G.; Méndez, A.; Shen, Y.; Paz-Ferreiro, J. Use of magnetic biochars for the immobilization of heavy metals in a multicontaminated soil. Sci. Total Environ. 2018, 622-623, 892-899. [CrossRef] [PubMed]

29. Lomaglio, T.; Hattab-Hambli, N.; Bret, A.; Miard, F.; Trupiano, D.; Scippa, G.S.; Motelica-Heino, M.; Bourgerie, S.; Morabito, D. Effect of biochar amendments on the mobility and (bio) availability of $\mathrm{As}, \mathrm{Sb}$ and $\mathrm{Pb}$ in a contaminated mine technosol. J. Geochem. Explor. 2017, 182, 138-148. [CrossRef]

30. Alidou-Arzika, I.; Lebrun, M.; Miard, F.; Nandillon, R.; Baycu, G.; Bourgerie, S.; Morabito, D. Assessment of compost and three biochars associated with Ailanthus altissima (Miller) Swingle for lead and arsenic stabilization in a post-mining Technosol. Pedosphere 2021, 31, 944-953. [CrossRef]

31. Gu, J.; Yao, J.; Duran, R.; Sunahara, G.; Zhou, X. Alteration of mixture toxicity in nonferrous metal mine tailings treated by biochar. J. Environ. Manag. 2020, 265, 110511. [CrossRef] [PubMed]

32. Paz-Ferreiro, J.; Gascó, G.; Gutiérrez, B.; Méndez, A. Soil biochemical activities and the geometric mean of enzyme activities after application of sewage sludge and sewage sludge biochar to soil. Biol. Fertil. Soils 2012, 48, 511-517. [CrossRef]

33. Liang, C.; Zhu, X.; Fu, S.; Méndez, A.; Gascó, G.; Paz-Ferreiro, J. Biochar alters the resistance and resilience to drought in a tropical soil. Environ. Res. Lett. 2014, 9, 064013. [CrossRef]

34. Lehmann, J.; Rillig, M.C.; Thies, J.; Masiello, C.A.; Hockaday, W.C.; Crowley, D. Biochar effects on soil biota-A review. Soil Biol. Biochem. 2011, 43, 1812-1836. [CrossRef]

35. Tu, C.; Wei, J.; Guan, F.; Liu, Y.; Sun, Y.; Luo, Y. Biochar and bacteria inoculated biochar enhanced Cd and Cu immobilization and enzymatic activity in a polluted soil. Environ. Int. 2020, 137, 105576. [CrossRef]

36. Wen, E.; Yang, X.; Chen, H.; Shaheen, S.M.; Sarkar, B.; Xu, S.; Song, H.; Liang, Y.; Rinklebe, J.; Hou, D.; et al. Iron-modified biochar and water management regime-induced changes in plant growth, enzyme activities, and phytoavailability of arsenic, cadmium and lead in a paddy soil. J. Hazard. Mater. 2021, 407, 124344. [CrossRef]

37. Álvarez, M.L.; Méndez, A.; Paz-Ferreiro, J.; Gascó, G. Effects of manure waste biochars in mining soils. Appl. Sci. 2020, 10, 3393. [CrossRef]

38. Lu, H.; Li, Z.; Fu, S.; Méndez, A.; Gascó, G.; Paz-Ferreiro, J. Can biochar and phytoextractors be jointly used for cadmium remediation? PLoS ONE 2014, 9, 95218. [CrossRef]

39. Zhang, F.P.; Li, C.F.; Tong, L.G.; Yue, L.X.; Li, P.; Ciren, Y.J.; Cao, C.G. Response of microbial characteristics to heavy metal pollution of mining soils in central Tibet, China. Appl. Soil Ecol. 2010, 45, 144-151. [CrossRef]

40. Paz-Ferreiro, J.; Liang, C.; Fu, S.; Méndez, A.; Gascó, G. The effect of biochar and its interaction with the earthworm Pontoscolex corethrurus on soil microbial community structure in tropical soils. PLoS ONE 2015, 10, e0124891. [CrossRef] [PubMed]

41. Stanislaw, W.; Gawronski, M.G.; Gawronska, H. Chapter 5: Plant Taxonomy and Metal Phytoremediation. In Detoxification of Heavy Metals; Sherameti, I., Varma, A., Eds.; Springer: Berlin/Heidelberg, Germany, 2011; pp. 91-109.

42. Lu, H.; Li, Z.; Fu, S.; Méndez, A.; Gascó, G.; Paz-Ferreiro, J. Combining phytoextraction and biochar addition improves soil biochemical properties in a soil contaminated with Cd. Chemosphere 2015, 119, 209-216. [CrossRef]

43. Pérez-Sirvent, C.; Hernández-Pérez, C.; Martínez-Sánchez, M.J.; García-Lorenzo, M.L.; Bech, J. Geochemical characterisation of surface waters, topsoils and efflorescences in a historic metal-mining area in Spain. J. Soils Sediments 2016, 16, 1238-1252 [CrossRef]

44. Benedicto, J.; Martínez- Gómez, C.; Guerrero, J.; Jornet, A.; Rodríguez, C. Metal contamination in Portman Bay (Murcía, SE Spain) 15 years after the cessation of mining activities. Ciencias Mar. 2008, 34, 389-398. [CrossRef]

45. ISO 23479; Determination of Effective Cation Exchange Capacity (CEC) and Exchangeable Cations Using a Hexaminecobalt Trichloride Solution. International Organization for Standardization: Geneva, Switzerland, 2007.

46. Nelson, D.W.; Sommers, L.E. Total Carbon, Organic Carbon and Organic Matter. In Methods of Soil Analysis. Part 3. Chemical Method; Bigham, J.M., Ed.; Soil Science Society of America: Madison, WI, USA, 1996; pp. 961-1010.

47. Watanabe, F.S.; Olsen, S.R. Test of an ascorbic acid method for determining phosphorus in water and $\mathrm{NaHCO}_{3}$ extracts from soils. Soil Sci. Soc. Am. J. 1965, 29, 677-678. [CrossRef]

48. United States Environmental Protection Agency. Method 3051a Microwave Assisted Acid Digestion of Sediments, Sluges, Solis and Oils; United States Environmental Protection Agency: Washington, DC, USA, 2007.

49. Vance, E.D.; Brookes, P.C.; Jenkinson, D.S. An extraction method for measuring soil microbial biomass C. Soil Biol. Biochem. 1987, 19, 703-707. [CrossRef]

50. Kabata-Pendias, A. Trace Elements in Soils and Plants, 3rd ed.; CRC Press: Boca Raton, FL, USA, 2001.

51. Al-Wabel, M.I.; Al-Omran, A.; El-Naggar, A.H.; Nadeem, M.; Usman, A.R.A. Pyrolysis temperature induced changes in characteristics and chemical composition of biochar produced from conocarpus wastes. Bioresour. Technol. 2013, 131, 374-379. [CrossRef]

52. Calvelo Pereira, R.; Kaal, J.; Camps Arbestain, M.; Pardo Lorenzo, R.; Aitkenhead, W.; Hedley, M.; Macías, F.; Hindmarsh, J.; Maciá-Agulló, J.A. Contribution to characterisation of biochar to estimate the labile fraction of carbon. Org. Geochem. 2011, 42, 1331-1342. [CrossRef]

53. Gaskin, J.W.; Steiner, C.; Harris, K.; Das, K.C.; Bibens, B. Effect of low-temperature pyrolysis conditions on biochar for agricultural use. Trans. ASABE 2008, 51, 2061-2069. [CrossRef] 
54. Figueiredo, C.; Lopes, H.; Coser, T.; Vale, A.; Busato, J.; Aguiar, N.; Novotny, E.; Canellas, L. Influence of pyrolysis temperature on chemical and physical properties of biochar from sewage sludge. Arch. Agron. Soil Sci. 2018, 64, 881-889. [CrossRef]

55. Antal, M.J.; Grønli, M. The art, science, and technology of charcoal production. Ind. Eng. Chem. Res. 2003, 42, 1619-1640. [CrossRef]

56. Ministerio de Agricultura, Pesca y Alimentación. Real Decreto 1310/1990, de 29 de Octubre, por el que se regula la utilización de los lodos de depuración en el sector agrario. Bol. Off. Estado 1990, 262, 32339-32340.

57. Cardenas-Aguiar, E.; Suarez, G.; Paz-Ferreiro, J.; Askeland, M.P.J.; Mendez, A.; Gascó, G. Remediation of mining soils by combining Brassica napus growth and amendment with chars from manure waste. Chemosphere 2020, 261, 127798. [CrossRef]

58. Bailey, V.L.; Fansler, S.J.; Smith, J.L.; Bolton, H. Reconciling apparent variability in effects of biochar amendment on soil enzyme activities by assay optimization. Soil Biol. Biochem. 2011, 43, 296-301. [CrossRef]

59. Ameloot, N.; Sleutel, S.; Case, S.D.C.; Alberti, G.; Mcnamara, N.P.; Zavalloni, C.; Vervisch, B.; Delle Vedove, G.; De Neve, S. C mineralization and microbial activity in four biochar field experiments several years after incorporation. Soil Biol. Biochem. 2014, 78, 195-203. [CrossRef]

60. Gascó, G.; Álvarez, M.L.; Paz-Ferreiro, J.; Méndez, A. Combining phytoextraction by Brassica napus and biochar amendment for the remediation of a mining soil in Riotinto (Spain). Chemosphere 2019, 231, 562-570. [CrossRef]

61. Cárdenas, E. Effects of the Combination of Organic Amendments and Phytoextraction Techniques through the Use of Two Plant Species (Brassica napus and Sinapis alba) in the Properties of Mining Soils in Spain. Ph.D. Thesis, Universidad Politécnica de Madrid, Madrid, Spain, 2019. 